\title{
VALUES AND PSYCHOLOGICAL WELLBEING OF YOUTH: A SUSTAINABLE INTERCONNECTION
}

\author{
Mayurakshee Gangopadhyay \\ Department of Human Development, Dum Dum Motijheel College, Kolkata, India \\ Email: psychologistm87@gmail.com
}

\begin{abstract}
Valu es play the most influential role in the well-being of individuals with a particularfocus on youth and their development. Psychological well-being refers to how people evaluate their lives. The purpose of this study was to determine the impact of values on the psychological well-being of adolescents. Using a quantitative research method, a sample of 300 adolescents aged 18 to 21 years was selected. The Personal Valu es Qu estionnaire bySherry and Verma, the Psychological Well-Being Scale by Sisodia and Choudhary and the General Information Schedule were provided to them. The results showed that the dimensions of personal values have a significant positive correlation with the dimensions of adolescent psychological well-being. All dimensions of psych ological well-being are shown to be positively predicted by values.
\end{abstract}

Key Words: Values, Youth, Psychological Well-Being

\begin{abstract}
ABSTRAK
Nilai memainkan peran yang paling berpengaruh dalam kesejahteraan individu dengan fokus khusus pada pemuda dan perkembangan mereka. Kesejahteraan psikologis mengacu pada bagaimana orang mengevaluasi hidup mereka. Tujuan penelitian ini adalah untuk mengetahui pengaruh nilai-nilai terhadap kesejahteraan psikologis remaja. Dengan menggunakan metode penelitian kuantitatif, dipilih 300 remaja usia 18 sampai 21 tahun. Kuesioner Nilai-Nilai Pribadi oleh Sherry dan Verma, Skala Kesejahteraan Psikologis oleh Sisodia dan Choudhary dan Jadwal Informasi Umum diberikan kepada mereka. Hasil penelitian menunjukkan bahwa dimensi nilai-nilai pribadi mempunyai hubungan positif yang signifikan dengan dimensi kesejahteraan psikologis remaja. Semua dimensi kesejahteraan psikologis terbukti diprediksi secara positif oleh nilai-nilai.
\end{abstract}

Kata Kunci: Nilai, Remaja, Psikologis Sejahtera

\section{INTRODUCTION}

It is important to change or fully alter some of the valuesin order to enhance the quality of lifeand to recognize the ways in which this can be created.Knowledge of the soundness of the principles to which individuals adhere and on which individuals develop their ability to make correct decisions is also needed. Via value orientation, this can be done (Muratori et al., 2014). A threefold method to judge the soundness of our valuescan be followed: firstly, by identifying the developments which give rise to the realization of the currently-dominating values we subscribe to; secondly, by isolating factors which tend to preserve or undermine such values; and, thirdly, by providing strategies and techniques for determining the degree of soundness of such values. In this context what is more important is to identify a person's or a society's values; how to satisfy them; how to identify their structure; how the values are oriented; and then to observe if any changesare evident in such orientation. The psychology of a person or a group is developed

\footnotetext{
* Copyright (c) 2021 Mayurakshee Gangopadhyay

This work is licensed under a Creative Commons Attribution-ShareAlike 4.0 International License.
} 
by the uniqueness of cultures; ethnocentricity, theological bias, social inhibitions and traditions (Chebotareva, 2015). Values are considered here to help meet the fundamental needs that will undoubtedly lead to growth, self-actualization and well-being in turn. It focuses on the core principle of well-being, i.e. therealization of oneself.Through this, a person can fulfill three fundamental psychological needs, especially

Attempts have been made to connect three fundamental needs to personal values theoretically (Bhutia, 2013; Gupta,2016). For example, several theorists linked Schwartz'svalues to thebasicneeds of self-determination theory, suggesting theoretical connections between values and well-being (the viewpoint of "healthy" values). With regard to the viewpoint of Schwartz's ideals, the values of selfdirection and relaxation are required to contribute to the fulfillment of the needs of autonomy, universalism and benevolence of the needs of relationships, and to the achievement of the needs of competence. Achieving these above values depends on (1) gaining social acceptance and material benefits (i.e. power) or (2) meeting other people's standards and avoiding the penalties they can impose (i.e., conformity, tradition), Or (3) to gain protection and to escape harm (i.e., security). This disparity between healthy and unhealthy values is attractive and, in part, relates to the difference between values of development (i.e. self-transcendence and willingness to change) and values of anxiety-avoidance (Schwartz, 2012). Thus values and well-beingare intertwined and one affects the other either positively or somewhere deficient in one factor deteriorates the other or in cases of other important forces such as basic values of culture and indicators of well-being, itcan be reversed. A strong definition of well-being is required in this context to draw on it.

A research byKumar and Subramanian (2012) found that psychological well-being is substantially diminished by hedonistic beliefs. The values of self-improvement are negative and the values of self transcendence are positively associated with psychological well-being. In her research, Jariwala-Parikh (2015) found no major association between values and psychological well-beingamongadults. Studies on beliefs and subjective well-being were done by Diener et al (2003) and Sagiv and Schwartz (2000). In the area of subjective well-being, there were important individual variations that were mostclosely linked to global life satisfaction. Moreover, these individual variations were systematically linked to meaning orientations in the patterns of subjective well-being. Sheldon et al. Bailey \& Phillips (2016) and Stumblingbear-Riddle \& Romans (2012) found that culture is consistently connected to subjective wellbeing in their study. In their study on youth and their moral values, George and Uyanga (2014) revealed that as young people are prepared for leadership roles, it is necessary to acquire moral standards and values that will form them into personalities ready to contribute to the advancement of society. In their study, Diener et al. (2003) found that personality, culture and subjective well-being are interrelated variables, and culture often moderates the variables that affect subjective well-being. However research on these studies is indispensable for thatwe are doing the latestresearch for finding out the influences of on the psychological well-being of youth. Objectives of this study include:

1. To assess the impact of gender (Male and Female) on different dimensions of values of youth.

2. To assess the impact of gender (Male and Female) on different dimensions of psychological wellbeing of youth.

3. To assess the relationship between values and psychological well-being of youth.

4. To assess whether the dimensions of psychological well being can be predicted byvalues. 


\section{Khazanah Pendidikan Islam, Vol. 3 No. 1: 30 - 40}

Values And Psychological Wellbeing Of Youth: A Sustainable Interconnection

Mayurakshee Gangopadhyay

\section{RESEARCHMETHOD}

This research uses quantitativeresearch methods with the following details (Creswell, 2014):

\section{Hypothesis}

1. Gender (Maleand Female) has significantimpact on the different dimensions of values of youth.

2. Gender (Male and Female) has significant impact on the different dimensions of psychological wellbeing of youth.

3. There is significant relationship between values and psychological well-being of youth.

4. The dimensions of psychological well being can be predicted by the values.

\section{Sample}

The samples were collected using a stratified random sampling technique from colleges located in Kolkata. Between 18 and 21 years of age, the samplesize was 300 , of which 150 were male and 150 were female.

\section{Tools used}

The following tools were used in collecting data from the samples:

1. General Information Schedule

To get the demographic data, the General Information Schedule was used. A questionnaire was prepared to obtain knowledge from the sample, such as age, family type,family rituals, individual influence in the life of the individual, etc.

2. PersonalValues Questionnaire:SherryandVerma (1998)

In the indigenous cultural milieu of India, PVQ is prepared to evaluate human values. It includes 40 questions based on 10 types of values such as religion, social, democratic, aesthetic, economic, knowledge, hedonism, power, prestige of the family and heal th value.

3. PsychologicalWell Being Scale (PWBS): Sisodia and Choudhary (2005)

In five areas, such as satisfaction, effectiveness, sociability, mental health and interpersonal relationships, PWBS aims to identify the psychological well-being of individuals. It consists of 50 statements, each of which is assigned 5 response options. The scale's test-retest reliability was 0.87 and the scale's consistency value was 0.90 . The scale was validated and the coefficient obtained was 0.94 against the external criteria.

4. StatisticalAnalysis

For the verification of hypotheses, descriptive statistics, one-way ANOVA, correlation and regression analysis are being implemented.In "SPSS-20" all the statistical analysis wascarried out. 


\section{RESULTS AND DISCUSSION}

\section{Result}

Table 1. Descriptive Statistics

\begin{tabular}{|c|c|c|c|c|c|c|c|}
\hline & Variables & \multicolumn{3}{|c|}{ Mean } & \multicolumn{3}{|c|}{ Std. Deviation } \\
\hline \multirow{11}{*}{$\begin{array}{l}\mathrm{I} \\
\mathrm{N} \\
\mathrm{D} \\
\mathrm{E} \\
\mathrm{P} \\
\mathrm{E} \\
\mathrm{N} \\
\mathrm{D} \\
\mathrm{E} \\
\mathrm{N} \\
\mathrm{T}\end{array}$} & & Male & Female & Total & Male & Female & Total \\
\hline & Religious value & 1165 & 15,44 & 1354 & 180 & 340 & 332 \\
\hline & Social value & 16.20 & 17.26 & 16.73 & 3.63 & 3.58 & 3.64 \\
\hline & Democratic value & 16.57 & 13.72 & 15.14 & 2.81 & 2.61 & 3.06 \\
\hline & Aesthetic value & 14.67 & 12.79 & 13.73 & 2.96 & 2.66 & 2.97 \\
\hline & Economic value & 14.30 & 11.77 & 13.04 & 3.11 & 2.42 & 3.06 \\
\hline & Knowledge value & 14.12 & 12.00 & 13.06 & 2.42 & 2.59 & 2.72 \\
\hline & Hedonistic value & 12.85 & 11.29 & 12.07 & 1.79 & 2.07 & 2.09 \\
\hline & Power value & 13.43 & 10.84 & 12.13 & 2.37 & 2.26 & 2.65 \\
\hline & $\begin{array}{l}\text { Family } \\
\text { prestige value }\end{array}$ & 14.23 & 17.34 & 15.78 & 2.66 & 2.41 & 2.98 \\
\hline & Health value & 10.19 & 12.23 & 11.21 & 2.66 & 2.06 & 2.59 \\
\hline \multirow{8}{*}{$\begin{array}{l}\mathrm{D} \\
\mathrm{E} \\
\mathrm{P} \\
\mathrm{E} \\
\mathrm{N} \\
\mathrm{D} \\
\mathrm{E} \\
\mathrm{N} \\
\mathrm{T}\end{array}$} & & & & & & & \\
\hline & Satisfaction & 32.44 & 29.47 & 30.96 & 2.78 & 1.77 & 2.77 \\
\hline & Efficiency & 36.32 & 31.99 & 34.15 & 2.77 & 3.50 & 3.83 \\
\hline & Sociability & 37.20 & 30.28 & 33.74 & 3.30 & 2.18 & 4.46 \\
\hline & Mental Health & 35.52 & 30.45 & 32.98 & 3.79 & 4.32 & 4.79 \\
\hline & $\begin{array}{l}\text { Interpersonal } \\
\text { Relations }\end{array}$ & 39.32 & 34.50 & 36.91 & 3.30 & 2.94 & 3.95 \\
\hline & PWBS & 182.88 & 156.63 & 169.76 & 7.79 & 7.23 & 15.14 \\
\hline & No. of Samples & 150 & 150 & $300(\mathrm{~N})$ & 150 & 150 & $300(\mathrm{~N})$ \\
\hline
\end{tabular}

Source : processed by Researcher (2020)

Table 1 shows the descriptive statistics i.e. the mean and standard deviation of the samples of both the genders, i.e. male and female and also of the total sample. It reveals that the means of different dimensions of values like democratic, aesthetic, economic, knowledge, hedonistic and power value and all dimensions of psychological well being like satisfaction, efficiency, sociability, mental health and over all psychological well-being are higher in case of male youth than females (Dadhania, 2015).The means of religious, social, family prestige and health value are higher among females than that of the male youth. 
Khazanah Pendidikan Islam, Vol. 3 No. 1: 30 - 40

Values And Psychological Wellbeing Of Youth: A Sustainable Interconnection

Mayurakshee Gangopadhyay

Table 2: Summarized Result of One Way ANOVAfor PersonalValues with respectto Gender

\begin{tabular}{lll}
\hline \multicolumn{1}{c}{ Dimensions of Personal Values } & df & \multicolumn{1}{c}{ F } \\
\hline Religious values & 1,298 & $\mathbf{1 4 4 . 9 5 * *}^{* *}$ \\
Social value & 1,298 & 6.48 \\
Democratic Value & 1,298 & $\mathbf{8 3 . 0 5}^{* *}$ \\
Aesthetic Value & 1,298 & $\mathbf{3 3 . 3 6}^{* *}$ \\
Economic Value & 1,298 & $\mathbf{6 1 . 8 2}^{* *}$ \\
Knowledge Value & 1,298 & $\mathbf{5 3 . 6 1}^{* *}$ \\
Hedonistic Value & 1,298 & $\mathbf{4 9 . 0 0}^{* *}$ \\
Power Value & 1,298 & $\mathbf{9 3 . 7 7}^{* *}$ \\
Family Prestige Value & 1,298 & $\mathbf{1 0 2 . 2 0}^{* *}$ \\
Health Value & 1,298 & $\mathbf{5 4 . 8 4}^{* *}$ \\
\hline
\end{tabular}

Information: ${ }^{* *} \mathrm{p}<0.01$

Source : processed by Researcher (2020)

The findings of One Way ANOVA in table 2 indicate that the impact of gender on the different dimensions of personal values have been found to be significant for all the dimensions except social value (Devi \& Deepika, 2014). Therefore the hypothesis i, i.e. Gender (Male and Female) has significant impact on the different dimensions of values of you th is accepted.

Table 3: Summarized Result of One Way ANOVAfor Psychological Well-Being with respect to Gender

\begin{tabular}{lcc}
\hline Dimensions of Psychological Well-Being & df & F \\
\hline Satisfaction & 1,298 & $\mathbf{1 2 1 . 1 9} * *$ \\
Efficiency & 1,298 & $\mathbf{1 4 1 . 2 8} * *$ \\
Sociability & 1,298 & $\mathbf{4 5 8 . 4 9} * *$ \\
MentalHealth & 1,298 & $\mathbf{1 1 6 . 5 8} * *$ \\
InterpersonalRelations & 1,298 & $\mathbf{1 7 7 . 9 4} * *$ \\
PWBS & 1,298 & $\mathbf{9 1 4 . 8 8} * *$ \\
\hline
\end{tabular}

Information: ${ }^{* *} \mathrm{p}<0.01$

Source : processed by Researcher (2020)

The findings of One Way ANOVA indicate that the impact of gender on the different dimensions of psychological well-being have been found to be largely significant see table 3 . Therefore the hypothesis ii, i.e. Gender (Maleand Female) has significantimpact on the different dimensions of psychological wellbeing of youth is accepted. 
Table 4: Summarized Result of Correlation for Personal Values and Psychological Well-Being

\begin{tabular}{|c|c|c|c|c|c|c|c|}
\hline $\begin{array}{c}\text { Dimensions } \\
\text { of Values }\end{array}$ & & Satisfaction & Efficiency & Sociability & $\begin{array}{l}\text { Mental } \\
\text { health }\end{array}$ & $\begin{array}{l}\text { Interpers } \\
\text { onal } \\
\text { relations }\end{array}$ & PWBS \\
\hline \multirow{2}{*}{$\begin{array}{l}\text { Religious } \\
\text { Value }\end{array}$} & Correlation & $-.282^{* *}$ & $-.313^{* *}$ & $-.451 * *$ & $-.263^{* *}$ & $-.292^{* *}$ & $-.461 * *$ \\
\hline & $\mathrm{N}$ & 300 & 300 & 300 & 300 & 300 & 300 \\
\hline \multirow{2}{*}{$\begin{array}{l}\text { Social } \\
\text { Value }\end{array}$} & Correlation & -.098 & $-.181^{* *}$ & $-.215^{* *}$ & $-.134^{*}$ & $-.185^{* *}$ & $-.218^{* *}$ \\
\hline & $\mathrm{N}$ & 300 & 300 & 300 & 300 & 300 & 300 \\
\hline \multirow{2}{*}{$\begin{array}{l}\text { Democratic } \\
\text { Value }\end{array}$} & Correlation & $.233^{* *}$ & $.240^{* *}$ & $.400^{* *}$ & $.256^{* *}$ & $.366^{* *}$ & $.438^{* *}$ \\
\hline & $\mathrm{N}$ & 300 & 300 & 300 & 300 & 300 & 300 \\
\hline \multirow{2}{*}{$\begin{array}{l}\text { Aesthetic } \\
\text { Value }\end{array}$} & Correlation & -.071 & $.186^{* *}$ & $.265^{* *}$ & $.217^{* *}$ & $.144^{*}$ & $.273^{* *}$ \\
\hline & $\mathrm{N}$ & 300 & 300 & 300 & 300 & 300 & 300 \\
\hline \multirow{2}{*}{$\begin{array}{l}\text { Economic } \\
\text { Value }\end{array}$} & Correlation & $.184 * *$ & $.234^{* *}$ & $.336^{* *}$ & $.258 * *$ & $.178^{* *}$ & $.332 * *$ \\
\hline & $\mathrm{N}$ & 300 & 300 & 300 & 300 & 300 & 300 \\
\hline \multirow{2}{*}{$\begin{array}{l}\text { Knowledge } \\
\text { Value }\end{array}$} & Correlation & $.228^{* *}$ & $.216^{* *}$ & $.262^{* *}$ & $.173^{* *}$ & $.211 * *$ & $.311 * *$ \\
\hline & $\mathrm{N}$ & 300 & 300 & 300 & 300 & 300 & 300 \\
\hline \multirow{2}{*}{$\begin{array}{l}\text { Hedonistic } \\
\text { Value }\end{array}$} & Correlation & $.286^{* *}$ & $.205^{* *}$ & $.290^{* *}$ & $.173^{* *}$ & $.269 * *$ & $332 * *$ \\
\hline & $\mathrm{N}$ & 300 & 300 & 300 & 300 & 300 & 300 \\
\hline \multirow{2}{*}{$\begin{array}{l}\text { Power } \\
\text { Value }\end{array}$} & Correlation & $.335^{* *}$ & $.351^{* *}$ & $.372^{* *}$ & $.294 * *$ & $.263^{* *}$ & $.447 * *$ \\
\hline & $\mathrm{N}$ & 300 & 300 & 300 & 300 & 300 & 300 \\
\hline \multirow{2}{*}{$\begin{array}{l}\text { Family } \\
\text { prestige } \\
\text { value }\end{array}$} & Correlation & $-.322^{* *}$ & $-.315^{* *}$ & $-.438^{* *}$ & $-.308 * *$ & $-.332 * *$ & $-.485^{* *}$ \\
\hline & $\mathrm{N}$ & 300 & 300 & 300 & 300 & 300 & 300 \\
\hline \multirow{2}{*}{$\begin{array}{l}\text { Health } \\
\text { Value }\end{array}$} & Correlation & $-.286^{* *}$ & $-.299 * *$ & $-.370^{* *}$ & $-.119 *$ & $-.158 * *$ & $-.332 * *$ \\
\hline & $\mathrm{N}$ & 300 & 300 & 300 & 300 & 300 & 300 \\
\hline
\end{tabular}

Information: ${ }^{* *} \mathrm{p}<0.01$

Source : processed by Researcher (2020)

In the table 4 sshow has been found to be highly significant between the dimensions of values and psychological well-being of youth except for social and aesthetic value with satisfaction. Therefore the hypothesisiii, i.e. there is significant relationship between values and psychological well-beingof youth is accepted.

Table 5: Regression Coefficient between Different Dimensions of Psychological Well-Being with Values

\begin{tabular}{|c|c|c|c|c|c|c|}
\hline & Dimensions of Psychological Well-Being (DV) & $\mathbf{R}$ & $\mathbf{R}^{\mathbf{2}}$ & $\mathbf{d f}$ & $\mathbf{F}$ & Sig \\
\cline { 2 - 7 } & Satisfaction & .505 & .255 & 10,289 & $9.89^{* *}$ & .000 \\
\cline { 2 - 7 } & Efficiency & .524 & .275 & 10,289 & $10.95^{* *}$ & .000 \\
\cline { 2 - 7 } & Sociability & .700 & .490 & 10,289 & $27.72^{* *}$ & .000 \\
\cline { 2 - 7 } & Mental Health & .459 & .211 & 10,289 & $7.72^{* *}$ & .000 \\
\cline { 2 - 7 } & Interpersonal Relations & .523 & .274 & 10,289 & $10.89^{* *}$ & .000 \\
\cline { 2 - 7 } & Psychological Well-Being & .741 & .549 & 10,289 & $35.12^{* *}$ & .000 \\
\hline
\end{tabular}


Khazanah Pendidikan Islam, Vol. 3 No. 1: 30 - 40

Values And Psychological Wellbeing Of Youth: A Sustainable Interconnection

Mayurakshee Gangopadhyay

\begin{tabular}{|c|c|c|c|c|c|}
\hline \multirow{8}{*}{ } & \multirow[t]{2}{*}{ Dimensions of Psychological Well-Being (DV) } & \multicolumn{2}{|c|}{ Unstandardized Coefficient } & \multirow[t]{2}{*}{$\mathbf{t}$} & \multirow[t]{2}{*}{ Sig } \\
\hline & & $\mathbf{B}$ & Std. Error & & \\
\hline & Satisfaction & 28.85 & 3.30 & $10.06^{* *}$ & .000 \\
\hline & Efficiency & 33.20 & 2.44 & $14.70^{* *}$ & .000 \\
\hline & Sociability & 33.92 & 3.22 & $10.52^{* *}$ & .000 \\
\hline & Mental Health & 27.19 & 4.31 & $6.31^{* *}$ & .000 \\
\hline & Interpersonal Relations & 34.04 & 3.41 & 9.99** & .000 \\
\hline & Psychological Well-Being & 156.93 & 10.30 & $15.23^{* *}$ & .000 \\
\hline
\end{tabular}

Information: ${ }^{* *} \mathrm{p}<0.01$

Source : processed by Researcher (2020)

In table 5 Regression equations have been generated for different dimensions of psychological wellbeing as dependent variable and values as independent variable for the entire sample. The highest Regression Coefficientfor the dimension of psychological well-being accounts for 54.9 percent variability. The $\mathrm{F}$ values are found out to be significant for all the dimensions of psychological well-being. The Unstandardized Beta Coefficients indicates that personal values positively predict the dimensions of psychological well-being. The above analyses of regression coefficients lead to acceptance of the hypothesis iv, i.e. the dim ensions of psychological well being can be predicted by the values.

\section{Discussion}

Positive psychology deals with a "good life" concept that helps ind ividuals to find the positive aspects of experiences that makes thelife worthy of living. It mainly deals with the positive well -being of individual being, but at large it also gives importance to societal well-being. It is a foundation based on humanistic movement (Schneider, 2011). Positive psychology immensely focuses on health, well-being, happinessand positivity.

As a modern branch of psychology, positive psychologists have given importance on several areas and ways which are needed for a person's happy being (Shrestha, 2016). Family is the most important component that nurtures the happyminds of individuals with all itsresources and means. The relationship with friends, spouses, colleagues, and other social ties play a very significant role in sustaining positive well-being. Financial componentis also importantin life. But itfluctuates with time and lacks the strength of continuity to provide consistent positive well-being.

Positive psychology is defined by Martin (2006) as, "...the scientific study of positive human functioning and flourishing on various levels, including the biological, personal, relational, institutional, cultural and global dimensions of life." Positive psychology is centred on living according to the greatest value in life, i.e. those factors that contribute effectively to the well-lived and fulfilled life. A life full of meaningful experiences and engagements is what an individual wishes to have. This is called a good life. According to Marlin Seligman, "the good life" is "using your signature strengths every day to produce authentic happiness and abundant gratification (Seligman \& Csikszentmihalyi, 2014)."

Now psychological well-being is an integral component of positive psychologyasanindividual must be mentally happy. Other than that the satisfaction with their life will not be achieved. Every living being wants a happy satisfied life. If the mental health of the individuals is not taken care of and is not given importance then ultimately a heal thy and happylife will be far awayfrom reach. It is not possiblealways to be happy in every situation. Human life is full of stress, depressive moments and also full of struggle and 
despair. Death of near and dear ones and loss of loving relationships are unavoidable. In that context mental health gets fluctuated so often and that's also natural.

Psychological well-being of individuals depends on how effectively and meaningfully an individual is dealing with life events. The more positive an individual is towards accepting the negatives of life the better the mental health is. Though sustaining this equilibrium is tough but it is not i mpossible if proper measures, guidance and strategic interventions are taken. Mental health is such an area that requires constant control that should be done by the individual and if in any situation that individual feels requirement of professional help there should notbeany delay. In many countrieslike India, mental health issues are still a taboo. But this would be dangerous for an individual's psychological well-being. This mentality should notbe encouraged for the greater well-being of individuals, families and society too.

Indianyouth as discussed earlier is the strength of the country. Actually itistrue for each and every country.Still a developing country like India needs to utilise the strength of younggeneration to navigate more development ahead. That is why the well-being of theyoung population is very much important. This well-being includes not only physical health but also mental heal th. In making theyouth understand how important their mental health is there is immenseimportant role of family and educational institutions.

The values the childrenlearn from family and schoolsstay with them forever. Family is the bearer of all the values. Since birth a child starts acquiring family values which naturally nurtures the societal, cultural and traditional values. If a child receives proper care and affection in inculcating those values then the rest of the life gets more enriched to stay happy and healthy.Certain norms control and also regulate the energy individuals have positively. This positive direction towards utilizing the inner energy and strength of human being is nourished by the value system. Thus knowingly and unknowingly human beings work towards a value directed goal in their life. This journey would never be successful or be completed without appropriate mental state. Here comes the importance of mental health in an individual's life.

A happy mindalways acts as a catalyst to a healthy and fruitful life. People usually feel discomfort in moments of negative thoughts. But the values of lifeteach the peoplehow to deal with thosenegativities and how to foster the psychological well-being. This is not a far away thing to accomplish the needs of a human being now-a-day. But arational way of judging the importance of needs and following the hierarchy of needs properly an individual may avoid the threats to mental health issues considering those the only reason behind a life with no satisfaction. All an individual wants is to satisfy theneedsthrough whichever means possible. But the values help in stating the ways of controlling greed and placing in order the desirable options to fulfil the needs. This is the primary way of maintain a healthy lifestyle. Theyouth are bunch of needs and desires and hopes. Theyare always thriving towards achieving theirgoals. There is a need to get them directed in the right way through which they can fulfil everything that are logically and rationally suitable for their well-being. Valuesare the strong components thatprovide the inner strength and direction towards the right path (Costa Galinha \& Pais-Ribeiro, 2011). Young generation should thus be equipped with the core values of life to have a healthy psychological wellbeing.

\section{Implication}

This needs no mention that theyouth are easily diverted towards theeasy ways to gain success or towards the luxurious and glamorous things over the essentials. Therefore they are always at the risk of losing the path of virtue and honesty. They easily may choose a wrong way that goes against social ethics(Sayer, 2011). They are vulnerable in that way. They also are at risk of losing the balance of mental health due to provocations and lures to achieve easy success. This vulnerability should not be their 
weakness. From childhood an individual must be reared up with strong emotional balance and vir tues of life. The traditional values, cultural values, societal ethics, family norms, etc. nurture the entire life of human beings. There must not beany gender discrimination in teaching the virtues of values (Honmore \& Jadhav, 2015). Like girls should only know family prestigevalues and boys would notb e aware about that or boys should only know economic or knowledge values and girls should not or religious values are for girls only and boys need not to learn much of that, these kind of conservative mentalities are harm to the personal being and also to the society.

In many parts of India irrespective of urban rural setup there are gendered practices of providing knowledge of values. Girls are mostly neglected even now. But this should not be the case. The present study also revealed that gender has significant impact on dimensions of values and psychological wellbeing. Therefore a serious care is needed to ensure every individual irrespective of any discriminatory ground should not be neglected on thegrounds of transferring the knowledge of values and the essential commodities to sustain a healthy psychological well-being.

In the development of psychological well-being of an individual there is reflection of personal values as these two are interrelated and inter-influencing factors (Liu et al., 2019). Family is the core of social structure and a unit to carry forward the culture and value system. Youth being the primary workforce of a nation whose dutiful participation in society reflects in a country's progress needs a caring family, a resourceful and dynamic society and an enriched culture to help them in maintaining a healthy psychological well-being so that they can effectively interact with the cultural variations and needs of the hour. Along with it they need guidance to utilize and improvise the application of their personal values wherever they feel the need.

In emerging condition of needs of a stringent value system the value education must be incorporated in the educational system so that the basic traditional values can be taught to the children. It is also true that not every time it is possible to incorporate a systematic value understanding among children only through value education. The same has to be practiced inside family and neighbourhood too, lacking to which may not produce fruitful outcome amongst the children in their understanding and sense of responsibilities. Notonly in the childhood but in the process of development towards maturity the value education must continue.

Schools should have value education in their curriculum so that a propervalue system getsa scope to develop.Indian culture is deeply influenced by the value system India nurtures. The value education is such a deep rooted concept of Indian philosophy that deserves a fresh start in lieu with the present condition of India. India has multifaceted value system. Education is the way to spread itamong thenew generation who will grow up keeping the Indian value system at heart. The University Education Commission (1948-49) mentioned the various aspects of values like loyalty, courage, discipline, selfsacrifice and spirituality. The Secondary Education Commission (1952-53) laid special emphasis on the values like efficiency, good temper, cooperation, integrity, discipline, moral awareness etc. in the formation of character of the students. Teachers whileinteracting in the classroom pass values to the students both consciously and unconsciously. Value education helps in awakening the unconscious moral dimensions and capacities of individuals.

Thus the formal education system mustinclude value education in their curriculum. Since birth the family may play the role to incorporate value education through their practices among the children. They will grow up to responsible adults who will carry forward the values with them and thus the flow of Indian value system will sustain. Along with this the well-being of the individuals will be ensured and the value 
system of the society will flow through generation after generation to sustain the development of individuals.

Not only value education but an awareness regarding mental heal th at the grass root level is highly solicited. People still hesitate to admit psychological issues and naturally they neglect the need of treatment also. Regular counselling and guidance services have to be present in every educational institutions, in every government health care set up and also at the community level dedicated mental health workers should work with an aim to address mental health issues. The quality of life and satisfaction with life should also be measured in regular intervals. Children and youth must be given greater emphasis in leading a quality life with the practice of value system and not exceeding any means that violate the societal norms. The sense of integrity as a social human being must be nurtured in their minds. Gradually this will lead to fulfilment of the basic need of psychological well-being. Thus values and psychological wellbeing are connected and dependent on one another. The young population of a country must have that opportunity to know the values and to know how to facilitate their psychological well-being. Itisa life-long continuous process thatneeds proper interventions in between as required.

\section{CONCLUSION}

The analysis of the findings reveals that gender has significant impact on different dimensions of values and psychological well-being. It proves appropriately that in the Indian society and culture the distinction between male and female population is still now vivid and that is also a part of the way they acquire values from their ancestors and also from their family and society. Urban and rural culture and its practices, family structure and traditional practices, social norms are reasons behind this difference. Personal values and psychological well-being is highly correlated with each other as found out from the analysis. Thus the role of values in inculcatinghealthy well-being of individuals is extrem ely important. It can also be said that individuals' personal beliefs affect their psychological well-being. In forming one's personal beliefs, social standards, traditions, customs, rituals, traditional norms, ethics, cultural components are essential influencesand thus inevitably affect the in dividual's psychological well-being..

\section{BIBLIOGRAPHY}

Bailey, T. H., \& Phillips, L. J. (2016). The influence of motivation and adaptation on students' subjective well-being, meaning in life and academic performance. Higher Education Research \& Development, 35(2), 201-216.

Bhutia, Y. (2013). Personal values of secondary school students. Inter J. Edu. Psychol. Res, 2, 129136.

Chebotareva, E. (2015). Cultural specifics of life values and subjective well-being. Mediterranean Journal of Social Sciences, 6(2 S5), 301.

Costa Galinha, I., \& Pais-Ribeiro, J. L. (2011). Cognitive, affective and contextual predictors of subjective wellbeing. International Journal of Wellbeing, 2(1), 34-53.

Creswell, J. W. (2014). A concise introduction to mixed methods research. SAGE publications.

Dadhania, D. A. (2015). Mental health and psychological well-being in adolescence boys and girls. International Journal OfPublic MentalHealth AndNeuro-Sciencesr, 2(3).

Devi, Y. A., \& Deepika, V. (2014). A comparative study of personal values profile of rur al and urban adolescents. Asian Journal of Home Science, 9(1), 128-133.

Diener, E., Oishi, S., \& Lucas, R. E. (2003). Personality, culture, and subjective well-being: Emotional and cognitive evaluations of life. Annual Review of Psychology, 54(1), 403-425. 
George, I. N., \& Uyanga, U. D. (2014). Youth and moral values in a changing society. IOSR Journal of Humanities and Social Science (IOSR-JHSS), 19(6), 40-44.

Gupta, G. (2016). A Comparative Study of Personal Values of Male and Female Secondary Teachers of Rewari District. The International Journal of Indian Psychology, Volume 3, Issue 3, No. 8 , 96.

Honmore, V. M., \& Jadhav, M. G. (2015). Psychological well-being, gender and optimistic attitude among college students. The International Journal of Indian Psychology, 3(1), 175-184.

Jariwala-Parikh, K. M. (2015). Quality of life and healthcare utilization and costs among adults with autism [US: ProQuest Information \& Learning]. http://gateway.proquest.com/openurl?url_ver=Z39.882004\&rft_val_fmt=info:ofi/fmt:kev :mtx:dissertation\&res_dat=xri:pqm\&rft_dat=xri:pqdiss:3707661

Kumar, V. V. B., \& Subramanian, S. (2012). Correlates of Psychological Well-Being with Reference Personal Values. Indian Journal of Health and Well-Being, 3(3), 711-715.

Liu, X., Ping, S., \& Gao, W. (2019). Changes in undergraduate students' psychological well-being as they experience university life. International Journal of Environmental Research and Public Health, 16(16), 2864.

Martin, J. (2006). Self research in educational psychology: A cauti onary tale of positive psychology in action. The Journal of Psychology, 140(4), 307-316.

Muratori, M., Beramendi, M., \& Zubieta, E. (2014). Psychological and Social well-being: themediated role of values. Juillet 2014 .

Sagiv, L., \& Schwartz, S. H. (2000). Value priorities and subjective well-being: Direct relations and congruity effects. European Journal of Social Psychology, 30(2), 177-198.

Sayer, A. (2011). Why things matter to people: Social science, values and ethical life. Cambridge University Press.

Schneider, K. (2011). Toward a humanistic positive psychology. existential analysis. Journal of the Society for Existential Analysis, 22(1), 32-38.

Schwartz, S. H. (2012). An overview of the Schwartz theory of basic values. Online Readings in Psychology and Culture, 2(1), 919-2307.

Seligman, M. E., \& Csikszentmihalyi, M. (2014). Positive psychology: An introduction (pp. 279-298). Netherlands. Springer.

Sherry, G. P., \& Verma, R. P. (1998). Manual for Personal Values Questionnaire. National Psychological Corporation.

Shrestha, A. K. (2016). Positive psychology: Evolution, philosophical foundations, and present growth. Indian Journal of Positive Psychology, 7(4), 460.

Sisodia, D. S., \& Choudhary, P. (2005). Psychological well-being scale. National Psychological Corporation, Agra.

Stumblingbear-Riddle, G., \& Romans, J. S. C. (2012). Resilience among urban American Indian adolescents: exploration into the role of culture, self-esteem, subjective well-being, and social support. American Indian and Alaska Native Mental Health Research: The Journal of the National Center, 19(2), 1-19. 